\title{
The Multi-Resistant Reaction of Drought-Tolerant Coffee 'Conilon Clone 14' to Meloidogyne spp. and Late Hypersensitive-Like Response in Coffea canephora
}

\author{
Edriana A. Lima, Cleber Furlanetto, Michel Nicole, Ana C. M. M. Gomes, Maria R. A. Almeida, Aldemiro Jorge-Júnior, \\ Valdir R. Correa, Sônia Maria Salgado, Maria A. G. Ferrão, and Regina M. D. G. Carneiro
}

First and second authors: Depto de Fitopatologia, Universidade de Brasília, 70910-900 Brasília, DF, Brazil; third author: IRD, UMR RPB F-34394 Montpellier, France; fourth, fifth, sixth, seventh, and tenth authors: Embrapa Recursos Genéticos e Biotecnologia, Laboratório de Nematologia, C.P. 02372, 70849-970 Brasília, DF, Brazil; eighth author: Empresa de Pesquisa Agropecuária de Minas Gerais/EPAMIGURESM, C.P. 176, 37200-000 Lavras, MG, Brazil; and ninth author: INCAPER/Embrapa Café, Rod BR 363, Km 94, $29375-000$ Domingos Martins, ES, Brazil.

Accepted for publication 13 February 2015.

\begin{abstract}
Lima, E. A., Furlanetto, C., Nicole, M., Gomes, A. C. M. M., Almeida, M. R. A., Jorge-Júnior, A., Correa, V. R., Salgado, S. M., Ferrão, M. A. G., and Carneiro, R. M. D. G. 2015. The multi-resistant reaction of droughttolerant coffee 'Conilon clone 14' to Meloidogyne spp. and late hypersensitivelike response in Coffea canephora. Phytopathology 105:805-814.

Root-knot nematodes (RKN), Meloidogyne spp., have major economic impact on coffee production in Central and South America. Genetic control of RKN constitutes an essential part for integrated pest management strategy. The objective of this study was to evaluate the resistance of Coffea canephora genotypes (clones) to Meloidogyne spp. Sensitive and drought-tolerant coffee genotypes were used to infer their resistance using nematode reproduction factor and histopathology. Eight clonal genotypes were highly resistant to M. paranaensis. 'Clone 14' (drought-tolerant) and 'ESN2010-04' were the only genotypes highly resistant and moderately resistant, respectively, to both $M$. incognita races

3 and 1 . Several clones were highly resistant to both avirulent and virulent M. exigua. Clone 14 and ESN2010-04 showed multiple resistance to major RKNs tested. Roots of 'clone 14' (resistant) and 'clone 22' (susceptible) were histologically studied against infection by $M$. incognita race 3 and $M$. paranaensis. Reduction of juvenile (J2) penetration in clone 14 was first seen at 2 to 6 days after inoculation (DAI). Apparent early hypersensitive reaction (HR) was seen in root cortex between 4 and 6 DAI, which led to cell death and prevention of some nematode development. At 12 to $20 \mathrm{DAI}$, giant cells formed in the vascular cylinder, besides normal development into J3/J4. From 32 to 45 DAI, giant cells were completely degenerated. Late, intense HR and cell death were frequently observed around young females and giant cells reported for the first time in coffee pathosystem. These results provide rational bases for future studies, including prospection, characterization, and expression profiling of genomic loci involved in both drought tolerance and resistance to multiple RKN species.
\end{abstract}

Root-knot nematodes (RKN), Meloidogyne spp., represent major threat to most coffee-growing areas worldwide. Currently, 17 RKN species have been reported as pathogenic to coffee $(19,42)$. Among the most damaging species, $M$. exigua Göldi 1887, M. incognita (Kofoid \& White), Chitwood 1949, and M. paranaensis Carneiro et al. 1996 constitute serious agronomic constraint to coffee due to their wide distribution and damage in Central and South America (17).

Genetic control of RKN is an essential part for integrated pest management strategy since the use of resistant cultivars or rootstocks constitutes an effective, inexpensive, nonpolluting method of control (11). Resistance to $M$. exigua has been sought in coffee germplasm of several countries (Brazil, Colombia, and Central America). To date, no resistance has been found in several Coffea arabica cultivars (Caturra, Catuaí, Mundo Novo, among others) or in wild coffee trees collected in Ethiopia $(9,13,20,25,26,36)$. In contrast, several resistant accessions have been identified in $C$. canephora and in some progenies of interspecific hybrids - i.e., C. arabica $\times$ C. canephora $(2,10,13,34,53)$. In $C$. arabica, all cultivars have been considered susceptible to $M$. incognita (33) and $M$. paranaensis $(7,8)$, while numerous wild coffee trees from Ethiopia were considered resistant to $M$. paranaensis $(7,8,16)$.

Corresponding author: R. M. D. G. Carneiro;

E-mail address: regina.carneiro@embrapa.br

http://dx.doi.org/10.1094/PHYTO-08-14-0232-R

(C) 2015 The American Phytopathological Society
The resistant rootstocks 'Nemaya' (cross between $C$. canephora clones T3561 and T3751) and Apoatã IAC 2258 (C. canephora '2258' from the Catie germplasm collection, Turrialba, Costa Rica) were developed to collectively overcome major problems associated with RKN in Central America and Brazil $(6,26)$. C. arabica grafted on 'Nemaya' or 'Apoatã' is the only feasible control measure that allows economic return of coffee planted in areas infested with M. incognita, M. paranaensis, and M. arabicida López \& Salazar 1989. However, 'Apoatã' and 'Nemaya' rootstocks showed intolerance to drought during dry season under field conditions (W. Gonçalves, IAC, São Paulo, Brazil, personal communication).

Coffee breeding for durable resistance to $\mathrm{RKN}$ is now a major goal in coffee-producing countries. A few years ago, a simply inherited major gene (Mex-1) from the related coffee 'IAPAR 59' was found to confer resistance to M. exigua (46). Upon avirulent RKN infection, Mex-1-carrying coffee plants show hypersensitivelike symptoms around 4 to 6 days after inoculation (DAI), preventing formation of most giant cells (3).

The objective of this work was to investigate novel sources of resistance in Conilon coffee to major Meloidogyne spp. In this study, using standard pathogenicity assays we showed that Conilon coffee genotype 'clone 14', which is drought-tolerant $(22,29,48)$, showed resistance to three highly aggressive RKN species (e.g., $M$. exigua, M. incognita, and $M$. paranaensis). We then examined histological alterations in susceptible and resistant coffee genotypes following infection with $M$. incognita and $M$. paranaensis in order 
to assess new defense mechanisms that may operate to resist nematode infection in roots of $C$. canephora.

\section{MATERIALS AND METHODS}

Clonal varieties of $\boldsymbol{C}$. canephora. In the first inoculation test we used the clonal variety Vitória-Incaper 8142 released in 2004, including 13 superior clones selected among genetic materials considered elite by Incaper's breeding program (31). The other materials used in this study are also genotypes that showed superior agronomic traits in Incaper's breeding program. Most genotypes are part of one of the eight clonal varieties released and recommended by Incaper. Clones 14 and 120 are drought-tolerant $(22,29,48)$, while clones 109A and 22 are sensitive to drought (29). The 13 clones, ESN2010-01 to ESN2010-13, are promising varieties for breeding programs, including rust resistance (M. A. Ferrão, Incaper, Vitória, ES, Brazil, personal communication). The cultivar Catuaí Vermelho IAC 81 was used as susceptible control. In the first pathogenicity assay, we tested clones Vitória-Incaper 8142 (V1 to V13), in addition to clones 14 and 22. The second assay included clones 109A, 120, and ESN2010-01 to ESN2010-13. In a third assay, clones 14 (resistant) and 22 (susceptible) used in the histopathological study were retested in the pathogenicity test.

Meloidogyne spp. populations. Five RKN populations from Brazil were used in this study. Species were identified using esterase phenotypes (Est) (18) and confirmed with sequence characterized amplified region-polymerase chain reaction (50). Races of $M$. incognita were characterized according to Hartman and Sasser (37). Meloidogyne incognita (Est I1) race 1 was obtained from Avilândia-SP, M. incognita (Est I2) race 3 from Londrina-PR, avirulent $M$. exigua (Est E2) from Lavras-MG, virulent $M$. exigua (Est E1) from Bom Jesus de Itabapoana-RJ, and M. paranaensis (Est P1) from Rolândia-PR. Meloidogyne populations were maintained on coffee plants 'IAC 15'.

Nematode inoculation. Prior to inoculation, RKN populations were multiplied in tomato (Solanum lycopersicum L. 'Santa Clara') for 3 months under greenhouse conditions. Eggs were extracted from infected roots using $0.5 \% \mathrm{NaOCl}$, according to Hussey and Barker (39), using a blender instead of manual agitation. For histopathological studies, freshly hatched second-stage juveniles (J2) were collected using a modified Baermann funnel. In both cases, counting was done under a light microscope using Peters' slides.

Experimental design. Inoculated plants were arranged in a completely randomized design with 80 treatments (16 coffee genotypes $\times 5$ Meloidogyne spp. populations) and eight replications. The inoculation assay was carried out in three separate experiments. The cultivar Catuaí Vermelho IAC 81 was used as susceptible check in all assays. In the first assay, clones Incaper 8142 (V1 to V13) and clones 14 (drought-tolerant) and 22 (droughtsensitive) were phenotyped. The second assay included genotype clones 109A, 120, and ESN2010-01 to ESN2010-13. In a third assay, clones 14 (resistant) and 22 (susceptible) used in the histopathological study were reinoculated to ensure their response against challenged nematodes.

Evaluation of nematode resistance in controlled conditions. Plants of each accession were grown in 3 liter pots filled with a mixture (1:1) of autoclaved soil and Plantimax compost under greenhouse conditions. Seedlings of about 15 to $20 \mathrm{~cm}$ height were inoculated with 10,000 eggs of Meloidogyne spp. by pipetting the nematode suspension around the stem base. Plants were arranged in the design mentioned above and maintained under greenhouse conditions at $\sim 25$ to $30^{\circ} \mathrm{C}$, with watering and fertilization as needed. Eight months after inoculation, the root system was rinsed with tap water and weighed. Roots were stained with phloxine B and evaluated for gall and egg mass numbers (galling index [GI] or egg mass index [EMI]), using a 0 to 5 scale, where $0=$ no galls or egg masses; $1=1$ to 2 galls or egg masses; $2=3$ to 10 galls or egg masses; $3=11$ to 30 galls or egg masses; $4=31$ to 100 galls or egg masses; and $5=>100$ galls or egg masses per root system (35).

Eggs were extracted as mentioned above using $1 \% \mathrm{NaOCl}$ and quantified under a light microscope using Peters' slides. The reproduction factor $(\mathrm{RF})$ was calculated as $\mathrm{RF}=\mathrm{FP} / \mathrm{IP}$, where $\mathrm{FP}=$ final nematode population and IP = initial nematode population $(\mathrm{IP}=10,000)$. The average RF was transformed as $\log (x+1)$, submitted to analysis of variance and the means separated using Scott-Knot's test $(P<0.05)$. Accessions for which $\mathrm{RF}<1$ were considered highly resistant (HR), while those for which $\mathrm{RF} \geq 1$ were considered moderately resistant (MR) or susceptible (S) (52). The highly resistant cultivar clone 14 and the susceptible clone 22 were retested to corroborate the resistance observed against $M$. incognita race 3 and $M$. paranaensis.

Histopathological observations. Plantlets of the resistant C. canephora clone 14 and the susceptible check clone 22 were grown in pots ( 3 liters) containing washed, sterilized, and weekly fertilized sand. Plantlets were inoculated with 20,000 J2 of $M$. incognita or $M$. paranaensis per plant. Three plantlets each of the resistant and susceptible, checked per time point, were carefully removed from cups at 2, 4, 8, 12, 16, 20,32, 38, 45, and 50 DAI, and their roots were rinsed with water. A portion of roots from susceptible and resistant plants were stained with acid fuchsin to observe $\mathrm{J} 2$ penetration, localization, and subsequent development within roots. After staining, root segments were observed under a stereo microscope and those parts that showed nematode infection were mounted on a glass slide for observation under light microscope (Axiophoto, Zeiss).

Subsamples of roots were embedded in resin to produce thin sections. Root fragments showing galls/swellings or without symptoms were excised under a stereo microscope, fixed, and embedded in Technovit 7100 epoxy resin (Kulzer Friedrichsdorf) as described by Pegard et al. (47) and according to the manufacturer's recommendations. Unstained root sections were mounted on glass slides and fluorescence was observed after UV excitation (UV filter set A2 Zeiss 02; 488002-0000). The same sections were subsequently stained $\left(1 \mathrm{~min}\right.$ at $\left.60^{\circ} \mathrm{C}\right)$ with $0.5 \%$ toluidine-blue in $0.1 \mathrm{M}$ sodium phosphate buffer, $\mathrm{pH} 5.5$, and observed using a light microscope.

\section{RESULTS}

Reaction of coffee genotypes to Meloidogyne spp. There were no differences among nematode populations and vegetative growth of coffee genotypes: plants showed no obvious above ground symptoms caused by Meloidogyne spp. This is probably due to frequent fertilization of coffee plants during the experiments.

Coffee resistance was evaluated based on three criteria: galling index (GI), egg mass index (EMI), and reproduction factor (RF). As expected, the susceptible check Catuaí 'IAC 81' exhibited high number of galls and egg masses, and high rate of nematode reproduction. The GI and EMI (Tables 1 to 7) were sometimes a subjective parameter because some species such as $M$. exigua forms typical galls whereas others do not (e.g., M. paranaensis and $M$. incognita). In some cases, egg masses of coffee roots infected with Meloidogyne spp., do not extend beyond root tissues and thus are not stained with phloxine $\mathrm{B}$, underestimating the real number of galls. Therefore, these two parameters are useful to describe symptoms but not to evaluate rates of nematode infection. Statistical analysis showed that GI and EMI (M. exigua) were correlated with coffee infection (RF) ( $r=0.58$ to $0.71 ; 0.35$ to 0.78 , respectively), however, sometimes with low Pearson correlation coefficient. For $M$. incognita and $M$. paranaensis, GI and EMI were not significantly correlated with RF, showing that these pathosystems do not allow evaluation of nematode infection using GI and EMI.

In the first assay, Incaper-Vitória clones $2 \mathrm{~V}, 3 \mathrm{~V}, 6 \mathrm{~V}, 7 \mathrm{~V}, 13 \mathrm{~V}$, and clone 14 were highly resistant to $M$. paranaensis $(\mathrm{RF}<1)$, while clones $1 \mathrm{~V}, 4 \mathrm{~V}, 5 \mathrm{~V}, 10 \mathrm{~V}, 12 \mathrm{~V}$, and clone 22 were susceptible $(\mathrm{RF} \geq 1)$ 
(Table 1). Considering the statistical analysis, clones $8 \mathrm{~V}, 9 \mathrm{~V}$, and $11 \mathrm{~V}$ were considered moderately resistant (MR) to this nematode.

Considering the reaction of coffee genotypes to $M$. incognita, clone 14 was the only one resistant to both races tested (races 1 and 3 ), whereas clones $2 \mathrm{~V}, 3 \mathrm{~V}, 6 \mathrm{~V}, 8 \mathrm{~V}$, and $13 \mathrm{~V}$ were highly resistant to $M$. incognita race 1 (Table 2). Our results demonstrated that $M$. incognita race 3 was more pathogenic to coffee genotypes than $M$. incognita race 1 . In addition, clones $6 \mathrm{~V}$ and $8 \mathrm{~V}$ can be considered moderately resistant (MR) to $M$. incognita race 3 and highly resistant (HR) to $M$. incognita race 1 , respectively (Table 2).

The avirulent population of $M$. exigua had a low reproduction rate on most clones $(\mathrm{RF}<1)$ (Table 3$)$. Clones $10 \mathrm{~V}$ and $13 \mathrm{~V}$ can be

TABLE 1. Mean values of fresh root mass (FRM), gall index (GI), egg mass index (EMI), and reproduction factor (RF) of coffee genotypes 8 months after inoculation with Meloidogyne paranaensis under controlled conditions

\begin{tabular}{lcllrl}
\hline Genotypes $^{w}$ & FRM $(\mathrm{g})$ & $\mathrm{GI}^{\mathrm{x}}$ & $\mathrm{EMI}^{\mathrm{x}}$ & $\mathrm{RF}^{\mathrm{y}}$ & $\mathrm{R}^{\mathrm{z}}$ \\
\hline Catuaí 'IAC 81'* & 23.00 & 4.50 & 4.43 & $29.33 \mathrm{a}$ & $\mathrm{S}$ \\
1V & 32.43 & 4.25 & 5.00 & $15.45 \mathrm{a}$ & $\mathrm{S}$ \\
2V & 22.37 & 2.50 & 0.00 & $0.25 \mathrm{~d}$ & $\mathrm{HR}$ \\
$3 \mathrm{~V}$ & 21.69 & 2.75 & 0.125 & $0.60 \mathrm{~d}$ & $\mathrm{HR}$ \\
$4 \mathrm{~V}$ & 28.00 & 3.75 & 4.00 & $7.96 \mathrm{~b}$ & $\mathrm{~S}$ \\
$5 \mathrm{~V}$ & 41.75 & 3.75 & 3.25 & $8.23 \mathrm{~b}$ & $\mathrm{~S}$ \\
$6 \mathrm{~V}$ & 18.68 & 2.62 & 0.125 & $0.20 \mathrm{~d}$ & $\mathrm{HR}$ \\
$7 \mathrm{~V}$ & 20.81 & 2.87 & 2.25 & $0.61 \mathrm{~d}$ & $\mathrm{HR}$ \\
$8 \mathrm{~V}$ & 48.87 & 3.37 & 0.125 & $2.30 \mathrm{c}$ & $\mathrm{MR}$ \\
$9 \mathrm{~V}$ & 30.12 & 3.12 & 2.125 & $1.35 \mathrm{c}$ & $\mathrm{MR}$ \\
$10 \mathrm{~V}$ & 30.25 & 4.37 & 4.00 & $8.41 \mathrm{~b}$ & $\mathrm{~S}$ \\
$11 \mathrm{~V}$ & 29.44 & 3.50 & 3.00 & $1.53 \mathrm{c}$ & $\mathrm{MR}$ \\
12V & 32.93 & 3.50 & 4.625 & $7.38 \mathrm{~b}$ & $\mathrm{~S}$ \\
13V & 18.09 & 2.37 & 1.875 & $0.35 \mathrm{~d}$ & $\mathrm{HR}$ \\
Clone 14 & 16.25 & 3.00 & 0.00 & $0.51 \mathrm{~d}$ & $\mathrm{HR}$ \\
Clone 22 & 32.50 & 3.50 & 3.50 & $15.06 \mathrm{a}$ & $\mathrm{S}$ \\
\hline
\end{tabular}

$\mathrm{w} *$ indicates susceptible check.

${ }^{x}$ Mean values $(n=8)$ of gall and egg mass index rated on a 0 to 5 scale: $0=$ absence of galls or egg masses; $1=1$ to 2 galls or egg masses; $2=3$ to 10 galls or egg masses; $3=11$ to 30 galls or egg masses; $4=31$ to 100 galls or egg masses; and $5=$ over 100 galls or egg masses (54).

y Values $(n=8)$ of reproduction factor $(\mathrm{RF}=$ final population/10,000 eggs of M. paranaensis) were transformed as $\log (x+1)$. Means followed by different letters in the column are significantly different according to ScottKnot's test $(P<0.05)$. Coefficient of variation $=22 \%$.

${ }^{\mathrm{z}}$ Reaction of inoculated coffee genotypes: $\mathrm{S}=$ susceptible; HR = highly resistant; and $\mathrm{MR}=$ moderately resistant. considered MR. Regarding the virulent population of M. exigua, genotypes $1 \mathrm{~V}, 2 \mathrm{~V}, 4 \mathrm{~V}, 5 \mathrm{~V}, 7 \mathrm{~V}, 9 \mathrm{~V}, 11 \mathrm{~V}, 12 \mathrm{~V}$, and clone 14 were highly resistant $(\mathrm{RF}<1)$ (Table 3$)$. The other clones $3 \mathrm{~V}, 6 \mathrm{~V}, 8 \mathrm{~V}, 10 \mathrm{~V}$, $13 \mathrm{~V}$, and 22 showed $\mathrm{RF} \geq 1$ and were considered susceptible or MR.

In the second assay, with cultivar Catuaí Vermelho, the genotype clones 109A and 120, and ES clones N2010-06, ES-07, ES-08, ES09, ES-10, and ES-12 were susceptible to M. paranaensis (Table 4). ES clones N2010-01, 02, 03, 05, and 11 were classified as MR, while genotypes ESN2010-04 and ESN2010-13 were highly resistant (HR) to M. paranaensis (Table 4). Regarding M. incognita race 3, most genotypes were classified as susceptible, except ES N2010-04 was classified as MR (Table 5). For $M$. incognita race 1 , clones ESN2010-04, ESN2010-03, and ESN2010-13 were highly resistant and moderately resistant, respectively, while genotypes 109A, 120, and ESN2010-01, ES-02, ES-05, ES-06, ES-07, ES-08, ES-09, ES10, ES-11, and ES-12 were all susceptible (Table 5). For the avirulent M. exigua, most genotypes were highly resistant (clones 109A, 120, ESN2010-01, 02, 03, 04, 05, 06, 07, 08, 10, 11, 12, and 13) (Table 6). Only 'Catuaí Vermelho' and genotype ESN2010-09 allowed considerable reproduction of the avirulent $M$. exigua population (Table 6). Genotypes inoculated with virulent $M$. exigua population showed similar results. The cultivar Catuaí Vermelho was susceptible, while genotype ESN2010-09 behaved as MR. All other genotypes (109A and 120 and ES clones N2010-01, 02, 03, 04, 05, 06, 07, 08, 10, 11, and 12) behaved as highly resistant (Table 6).

The multi-resistant genotype Conilon clone 14 and clone 22, susceptible to $M$. paranaensis and $M$. incognita race 3, were confirmed with inoculation in the third assay (Table 7).

Histopathology of $M$. paranaensis and $M$. incognita in coffee genotypes. Histological features from ca. 10,000 root sections were observed in both susceptible (Fig. 1) and resistant (Fig. 2) C. canephora genotypes inoculated with $M$. incognita race 3 and $M$. paranaensis. Nematode-infected roots were compared with noninoculated controls (data not shown).

The susceptible $C$. canephora clone 22 and resistant clone 14 were chosen for the histopathological observations of resistance in compatible and incompatible interactions, respectively. Because reaction of these clones to both $M$. incognita race 3 and M. paranaensis was very similar, only results for the later species are shown.

Examination of acid fuchsine-stained roots and toluidine bluestained sections showed that $\mathrm{J} 2$ were able to penetrate root tips,

TABLE 2. Mean values of fresh root mass (FRM), gall index (GI), egg mass index (EMI), and reproduction factor (RF) of coffee genotypes 8 months after inoculation with Meloidogyne incognita races 1 and 3 under controlled conditions

\begin{tabular}{|c|c|c|c|c|c|c|c|c|c|c|}
\hline \multirow[b]{2}{*}{ Genotypesw $^{w}$} & \multicolumn{5}{|c|}{ M. incognita race 3} & \multicolumn{5}{|c|}{ M. incognita race 1} \\
\hline & FRM (g) & $\mathrm{GI}^{\mathrm{x}}$ & $\mathrm{EMI}^{\mathrm{x}}$ & $\mathrm{RF}^{\mathrm{y}}$ & $\mathrm{R}^{\mathrm{z}}$ & FRM (g) & $\mathrm{GI}^{\mathrm{x}}$ & EMI $^{x}$ & $\mathrm{RF}^{\mathrm{y}}$ & $\mathrm{R}^{\mathrm{z}}$ \\
\hline Catuaí 'IAC 81 '* & 42.43 & 4.88 & 4.87 & $111.8 \mathrm{a}$ & $\mathrm{S}$ & 45.75 & 4.87 & 5.0 & $30.83 \mathrm{a}$ & $\mathrm{S}$ \\
\hline $1 \mathrm{~V}$ & 52.56 & 3.13 & 5.0 & $34.0 \mathrm{a}$ & $\mathrm{S}$ & 23.44 & 4.0 & 4.25 & $13.8 \mathrm{~b}$ & $\mathrm{~S}$ \\
\hline $2 \mathrm{~V}$ & 27.87 & 2.75 & 4.25 & $4.08 \mathrm{~b}$ & $\mathrm{~S}$ & 38.81 & 1.75 & 2.62 & $0.68 \mathrm{~d}$ & HR \\
\hline $3 \mathrm{~V}$ & 42.93 & 2.5 & 2.62 & $6.35 \mathrm{~b}$ & $\mathrm{~S}$ & 54.50 & 2.75 & 0.37 & $0.78 \mathrm{~d}$ & HR \\
\hline $4 \mathrm{~V}$ & 36.06 & 2.0 & 4.37 & $10.01 \mathrm{~b}$ & $\mathrm{~S}$ & 20.94 & 2.87 & 3.87 & $11.18 \mathrm{~b}$ & $\mathrm{~S}$ \\
\hline $5 \mathrm{~V}$ & 14.31 & 3.0 & 4.87 & $6.31 \mathrm{~b}$ & $\mathrm{~S}$ & 55.56 & 2.62 & 4.0 & $2.38 \mathrm{c}$ & $\mathrm{S}$ \\
\hline $6 \mathrm{~V}$ & 24.12 & 2.75 & 1.75 & $2.0 \mathrm{c}$ & MR & 14.12 & 1.87 & 0.5 & $0.01 \mathrm{~d}$ & HR \\
\hline $7 \mathrm{~V}$ & 45.43 & 3.5 & 5.0 & $10.61 \mathrm{~b}$ & $\mathrm{~S}$ & 24.12 & 2.75 & 3.12 & $1.01 \mathrm{c}$ & MR \\
\hline $8 \mathrm{~V}$ & 71.37 & 3.13 & 1.5 & $2.48 \mathrm{c}$ & MR & 33.12 & 2.62 & 0.0 & $0.28 \mathrm{~d}$ & HR \\
\hline $9 \mathrm{~V}$ & 51.75 & 3.25 & 3.75 & $5.76 \mathrm{~b}$ & $\mathrm{~S}$ & 46.12 & 3.75 & 3.5 & $2.35 \mathrm{c}$ & $\mathrm{S}$ \\
\hline $10 \mathrm{~V}$ & 43.56 & 3.63 & 4.12 & $9.95 \mathrm{~b}$ & $\mathrm{~S}$ & 14.37 & 3.12 & 3.75 & $4.88 \mathrm{~b}$ & $\mathrm{~S}$ \\
\hline $11 \mathrm{~V}$ & 66.00 & 3.38 & 3.87 & $7.73 \mathrm{~b}$ & $\mathrm{~S}$ & 59.64 & 3.12 & 4.25 & $5.1 \mathrm{~b}$ & $\mathrm{~S}$ \\
\hline $12 \mathrm{~V}$ & 72.18 & 4.63 & 5.0 & $16.28 \mathrm{a}$ & $\mathrm{S}$ & 39.12 & 2.87 & 4.0 & $1.53 \mathrm{c}$ & $\mathrm{S}$ \\
\hline $13 \mathrm{~V}$ & 45.57 & 2.0 & 4.0 & $6.20 \mathrm{~b}$ & $\mathrm{~S}$ & 16.69 & 2.5 & 2.25 & $0.71 \mathrm{~d}$ & HR \\
\hline Clone 14 & 20.26 & 2.2 & 0.5 & $0.26 \mathrm{~d}$ & HR & 43.00 & 2.16 & 0.0 & $0.04 \mathrm{~d}$ & HR \\
\hline Clone 22 & 58.81 & 3.38 & 3.87 & $5.10 \mathrm{~b}$ & $\mathrm{~S}$ & 23.64 & 3.29 & 4.71 & $12.05 \mathrm{~b}$ & $\mathrm{~S}$ \\
\hline
\end{tabular}

w $*$ indicates susceptible check.

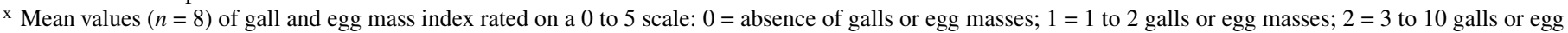
masses; $3=11$ to 30 galls or egg masses; $4=31$ to 100 galls or egg masses; and $5=$ over 100 galls or egg masses (54).

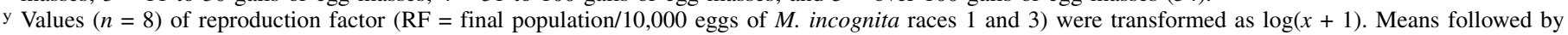
different letters in the column are significantly different according to Scott-Knot's test $(P<0.05)$. Coefficients of variation $=28$ and $31 \%$.

${ }^{\mathrm{z}}$ Reaction of inoculated coffee genotypes: $\mathrm{S}=$ susceptible; $\mathrm{HR}=$ highly resistant; and $\mathrm{MR}=$ moderately resistant. 
migrate along with sieve elements, and develop normally after having initiated differentiation into feeding sites (Fig. 1A to F). At 2 DAI, numerous $\mathrm{J} 2$ were observed localized in the subapical meristem of roots (Fig. 1A). At 4 DAI, J2 were present in the root cortex (Fig. 1B), probably migrating toward the vascular cylinder, thus causing cell wall damage. At 4 to $8 \mathrm{DAI}$, numerous $\mathrm{J} 2$ were observed within the vascular cylinder (Fig. 1B to C), and feeding J2 were visible inside the vascular cylinder at $8 \mathrm{DAI}$, close to giant cells (Fig. 1C). At 16 to 32 DAI, numerous J3/J4 had established feeding sites with 10 to 12 well-defined giant cells associated with each nematode (Fig. 1F). Giant cells were hypertrophied, oval-shaped, vacuolated and with dense cytoplasm containing some nuclei (Fig. $1 \mathrm{D}$ to $\mathrm{F})$. At this time, enlargement of the vascular cylinder region took place, and small galls were apparent. Giant cells displayed thickened cell walls (Fig. 1D and E). At 32 DAI, adult females were observed associated with severe injuries to the surrounding cells and disruption of root cortex. At 45 DAI, egg masses were observed inside and at root surface.

For the histopathological observations in the resistant C. canephora clone 14-M. paranaensis interactions, at 2 to 6 DAI, macroscopic observations of cleared roots stained with acid fuchsin revealed a reduced number of $\mathrm{J} 2$ in the subapical region compared with the distribution of nematodes in infected susceptible roots. At 4 DAI, infected samples of clone 14 showed that nematodes reached the vascular cylinder; however, no gall was observed at this time. Moreover, only J2 were detected until 6 DAI, indicating that a great majority of invading nematodes were not capable of proceeding to other stages in their life cycle within resistant roots. Fluorescence microscopy using UV excitation of root sections harvested at 8 DAI showed a strong yellowish autofluorescence around nematodes in every infection site examined (Fig. 2B). The same section visualized under bright field microscopy after toluidine-blue staining showed a bluish staining, indicating degradation of cells surrounding nematodes (Fig. 2A), which can be associated with an HR-like response. These HR-like lesions were found around nematodes when they were probably migrating through the cortex at early infection stage (Fig. 2A and B). At 8 DAI, some nematodes were seen close to feeding sites in which the giant cells displayed similar features to those in susceptible roots (Fig. 2C).

The main difference between the susceptible coffee clone 22 and the resistant clone 14 was detected at 12 to 20 DAI, when giant cells adjacent to nematodes in resistant roots displayed small to large vacuoles that sometimes occupied almost the entire volume of the cells, whereas giant cells in susceptible roots had uniformly dense cytoplasm with less vacuolization. At this time, $\mathrm{J} 2 / \mathrm{J} 4$ nematodes were present in the vascular cylinder (Fig. $2 \mathrm{C}$ to F). At 32 to 45 DAI, a complete degeneration of giant cells was observed (Fig. 2G to H). Fluorescence microscopy at 20 to 45 DAI, using UV excitation of root sections, showed a strong blue or gray autofluorescence around nematodes and giant cells in all infection sites examined. Observed under bright field after toluidine blue staining, the same sections revealed dark blue regions indicating major alterations of cells (cell death) in contact

TABLE 4. Mean values of fresh root mass (FRM), gall index (GI), egg mass index (EMI), and reproduction factor (RF) of coffee genotypes 8 months after inoculation with Meloidogyne paranaensis under controlled conditions

\begin{tabular}{lcllrl}
\hline Genotypesw $^{\mathrm{w}}$ & $\mathrm{FRM}(\mathrm{g})$ & $\mathrm{GI}^{\mathrm{x}}$ & EMI $^{\mathrm{x}}$ & $\mathrm{RF}^{\mathrm{y}}$ & $\mathrm{R}^{\mathrm{z}}$ \\
\hline Catuaí 'IAC 81'* & 29.58 & 4.17 & 4.33 & $11.66 \mathrm{a}$ & $\mathrm{S}$ \\
Clone 109A & 136.83 & 5.0 & 5.0 & $16.64 \mathrm{a}$ & $\mathrm{S}$ \\
Clone 120 & 100.0 & 4.8 & 3.8 & $4.13 \mathrm{~b}$ & $\mathrm{~S}$ \\
ES N2010-01 & 158.83 & 3.33 & 3.0 & $2.19 \mathrm{c}$ & $\mathrm{MR}$ \\
ES N2010-02 & 120.67 & 4.83 & 4.5 & $1.91 \mathrm{c}$ & $\mathrm{MR}$ \\
ES N2010-03 & 134.08 & 3.83 & 2.67 & $2.19 \mathrm{c}$ & $\mathrm{MR}$ \\
ES N2010-04 & 64.08 & 2.0 & 0.17 & $0.00 \mathrm{~d}$ & $\mathrm{I}$ \\
ES N2010-05 & 70.67 & 3.83 & 3.0 & $2.32 \mathrm{c}$ & $\mathrm{MR}$ \\
ES N2010-06 & 230.33 & 3.67 & 3.5 & $3.85 \mathrm{~b}$ & $\mathrm{~S}$ \\
ES N2010-07 & 145.83 & 4.83 & 4.5 & $5.88 \mathrm{~b}$ & $\mathrm{~S}$ \\
ES N2010-08 & 174.25 & 5.0 & 4.33 & $11.88 \mathrm{a}$ & $\mathrm{S}$ \\
ES N2010-09 & 119.5 & 4.83 & 4.67 & $11.75 \mathrm{a}$ & $\mathrm{S}$ \\
ES N2010-10 & 99.67 & 5.0 & 4.83 & $8.47 \mathrm{a}$ & $\mathrm{S}$ \\
ES N2010-11 & 123.5 & 3.83 & 3.83 & $2.04 \mathrm{c}$ & $\mathrm{MR}$ \\
ES N2010-12 & 120.92 & 4.67 & 4.67 & $13.96 \mathrm{a}$ & $\mathrm{S}$ \\
ES N2010-13 & 108.83 & 3.0 & 2.67 & $0.39 \mathrm{~d}$ & $\mathrm{HR}$ \\
\hline
\end{tabular}

$\mathrm{w} *$ indicates susceptible check.

${ }^{x}$ Mean values $(n=8)$ of gall and egg mass index rated on a 0 to 5 scale: $0=$ absence of galls or egg masses; $1=1$ to 2 galls or egg masses; $2=3$ to 10 galls or egg masses; $3=11$ to 30 galls or egg masses; $4=31$ to 100 galls or egg masses; and $5=$ over 100 galls or egg masses (54).

y Values $(n=8)$ of reproduction factor $(\mathrm{RF}=$ final population/10,000 eggs of M. exigua) were transformed as $\log (x+1)$. Means followed by different letters in the column are significantly different according to Scott-Knot's test $(P<0.05)$. Coefficient of variation $=29 \%$.

${ }^{\mathrm{z}}$ Reaction of inoculated coffee genotypes: $\mathrm{S}=$ susceptible; $\mathrm{HR}=$ highly resistant; $\mathrm{MR}=$ moderately resistant; and $\mathrm{I}=$ immune.

TABLE 3. Mean values of fresh root mass (FRM), gall index (GI), egg mass index (EMI), and reproduction factor (RF) of coffee genotypes 8 months after inoculation with avirulent and virulent Meloidogyne exigua populations under controlled conditions

\begin{tabular}{|c|c|c|c|c|c|c|c|c|c|c|}
\hline \multirow[b]{2}{*}{ Genotypes $^{w}$} & \multicolumn{5}{|c|}{ Virulent $M$. exigua } & \multicolumn{5}{|c|}{ Avirulent M. exigua } \\
\hline & FRM $(g)$ & $\mathrm{GI}^{\mathrm{x}}$ & EMI $^{\mathrm{x}}$ & $\mathrm{RF}^{\mathrm{y}}$ & $\mathrm{R}^{\mathrm{z}}$ & FRM $(\mathrm{g})$ & $\mathrm{GI}^{\mathrm{x}}$ & $\mathrm{EMI}^{\mathrm{x}}$ & $\mathrm{RF}^{\mathrm{y}}$ & $\mathrm{R}^{\mathrm{z}}$ \\
\hline Catuaí 'IAC $81^{\prime} *$ & 47.44 & 4.88 & 3.88 & $78.92 \mathrm{a}$ & $\mathrm{S}$ & 59.37 & 5.0 & 4.5 & $53.4 \mathrm{a}$ & $\mathrm{S}$ \\
\hline $1 \mathrm{~V}$ & 34.71 & 4.29 & 3.29 & $0.84 \mathrm{c}$ & HR & 48.07 & 0.29 & 0.57 & $0.82 \mathrm{c}$ & HR \\
\hline $3 \mathrm{~V}$ & 42.61 & 4.78 & 2.78 & $20.93 \mathrm{~b}$ & $\mathrm{~S}$ & 62.94 & 1.88 & 0.38 & $0.08 \mathrm{c}$ & HR \\
\hline $4 \mathrm{~V}$ & 43.0 & 3.5 & 0.33 & $0.02 \mathrm{~d}$ & HR & 38.44 & 0.25 & 0.13 & $0.07 \mathrm{c}$ & HR \\
\hline $5 \mathrm{~V}$ & 32.21 & 3.86 & 0.57 & $0.02 \mathrm{~d}$ & HR & 37.62 & 0.0 & 1.0 & $0.05 \mathrm{c}$ & HR \\
\hline $8 \mathrm{~V}$ & 60.94 & 3.88 & 1.5 & $1.07 \mathrm{c}$ & MR & 62.0 & 0.0 & 0.25 & $0.03 \mathrm{c}$ & HR \\
\hline $9 \mathrm{~V}$ & 59.31 & 2.75 & 0.38 & $0.02 \mathrm{~d}$ & HR & 56.0 & 0.0 & 0.0 & $0.06 \mathrm{c}$ & HR \\
\hline $10 \mathrm{~V}$ & 45.0 & 3.86 & 1.71 & $7.05 \mathrm{~b}$ & $\mathrm{~S}$ & 41.18 & 0.38 & 3.38 & $3.82 \mathrm{~b}$ & MR \\
\hline $11 \mathrm{~V}$ & 48.94 & 3.88 & 0.13 & $0.05 \mathrm{~d}$ & HR & 33.25 & 1.63 & 0.75 & $0.18 \mathrm{c}$ & HR \\
\hline $12 \mathrm{~V}$ & 45.75 & 1.83 & 0.0 & $0.84 \mathrm{~d}$ & HR & 62.87 & 0.0 & 1.38 & $0.4 \mathrm{c}$ & HR \\
\hline $13 \mathrm{~V}$ & 25.5 & 2.25 & 2.20 & $2.45 \mathrm{c}$ & MR & 39.72 & 0.78 & 1.56 & $1.44 \mathrm{~b}$ & MR \\
\hline Clone 14 & 38.92 & 2.83 & 0.0 & $0.04 \mathrm{~d}$ & HR & 47.33 & 0.0 & 0.0 & $0.0 \mathrm{c}$ & I \\
\hline
\end{tabular}

$\mathrm{w} *$ indicates susceptible check.

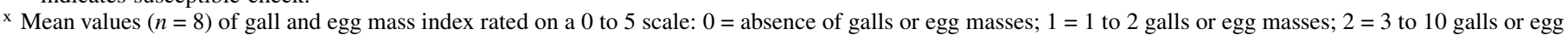
masses; $3=11$ to 30 galls or egg masses; $4=31$ to 100 galls or egg masses; and $5=$ over 100 galls or egg masses (54).

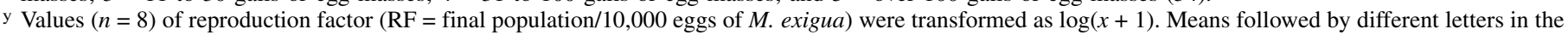
column are significantly different according to Scott-Knot's test $(P<0.05)$. Coefficients of variation $=32$ and $34 \%$.

${ }^{\mathrm{z}}$ Reaction of inoculated coffee genotypes: $\mathrm{S}=$ susceptible; $\mathrm{I}=$ immune; HR = highly resistant; and $\mathrm{MR}=$ moderately resistant. 


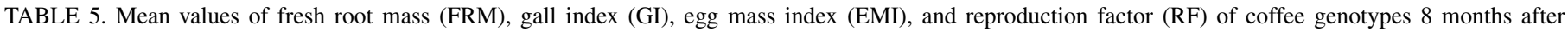
inoculation with Meloidogyne incognita races 1 and 3 under controlled conditions

\begin{tabular}{|c|c|c|c|c|c|c|c|c|c|c|}
\hline \multirow[b]{2}{*}{ Genotypes ${ }^{\mathrm{w}}$} & \multicolumn{5}{|c|}{ M. incognita race 3} & \multicolumn{5}{|c|}{$M$. incognita race 1} \\
\hline & FRM (g) & $\mathrm{GI}^{\mathrm{x}}$ & $\mathrm{EMI}^{\mathrm{x}}$ & $\mathrm{RF}^{\mathrm{y}}$ & $\mathrm{R}^{\mathrm{z}}$ & FRM (g) & $\mathrm{GI}^{\mathrm{x}}$ & $\mathrm{EMI}^{\mathrm{x}}$ & $\mathrm{RF}^{\mathrm{y}}$ & $\mathrm{R}^{\mathrm{z}}$ \\
\hline Catuaí 'IAC 81'* & 98.0 & 5.0 & 5.0 & $190.3 \mathrm{a}$ & $\mathrm{S}$ & 64.83 & 4.0 & 4.67 & $44.62 \mathrm{a}$ & $\mathrm{S}$ \\
\hline Clone 109A & 140.92 & 5.0 & 5.0 & $35.76 \mathrm{~b}$ & $\mathrm{~S}$ & 178.17 & 5.0 & 5.0 & $39.66 \mathrm{a}$ & $\mathrm{S}$ \\
\hline Clone 120 & 79.7 & 5.0 & 5.0 & $16.32 \mathrm{c}$ & $\mathrm{S}$ & 99.75 & 5.0 & 5.0 & $16.0 \mathrm{~b}$ & $\mathrm{~S}$ \\
\hline ES N2010-01 & 111.25 & 5.0 & 5.0 & $21.35 \mathrm{c}$ & $\mathrm{S}$ & 168.8 & 5.0 & 5.0 & $9.81 \mathrm{~b}$ & $\mathrm{~S}$ \\
\hline ES N2010-02 & 104.75 & 5.0 & 5.0 & $13.5 \mathrm{c}$ & $\mathrm{S}$ & 120.58 & 5.0 & 5.0 & $13.19 \mathrm{~b}$ & $\mathrm{~S}$ \\
\hline ES N2010-03 & 19.06 & 5.0 & 5.0 & $37.16 \mathrm{~b}$ & $\mathrm{~S}$ & 159.0 & 4.83 & 4.5 & $4.60 \mathrm{c}$ & MR \\
\hline ES N2010-04 & 150.08 & 4.83 & 3.83 & $2.29 \mathrm{~d}$ & MR & 123.0 & 1.17 & 0.0 & $0.0 \mathrm{~d}$ & $\mathrm{I}$ \\
\hline ES N2010-05 & 27.6 & 4.4 & 3.8 & $6.91 \mathrm{c}$ & $\mathrm{S}$ & 76.9 & 3.67 & 3.67 & $11.29 \mathrm{~b}$ & $\mathrm{~S}$ \\
\hline ES N2010-06 & 141.92 & 5.0 & 5.0 & $12.65 \mathrm{c}$ & $\mathrm{S}$ & 201.83 & 5.0 & 5.0 & $38.82 \mathrm{a}$ & $\mathrm{S}$ \\
\hline ES N2010-07 & 191.17 & 5.0 & 5.0 & $49.96 \mathrm{~b}$ & $\mathrm{~S}$ & 122.92 & 5.0 & 5.0 & $16.51 \mathrm{~b}$ & $\mathrm{~S}$ \\
\hline ES N2010-08 & 214.2 & 5.0 & 5.0 & $50.52 \mathrm{~b}$ & $\mathrm{~S}$ & 201.33 & 5.0 & 5.0 & $37.16 \mathrm{a}$ & $\mathrm{S}$ \\
\hline ES N2010-09 & 126.67 & 5.0 & 5.0 & $27.36 \mathrm{~b}$ & $\mathrm{~S}$ & 112.5 & 5.0 & 5.0 & $31.1 \mathrm{a}$ & $\mathrm{S}$ \\
\hline ES N2010-10 & 64.33 & 5.0 & 5.0 & $10.84 \mathrm{c}$ & $\mathrm{S}$ & 103.83 & 5.0 & 5.0 & $47.83 \mathrm{a}$ & $\mathrm{S}$ \\
\hline ES N2010-11 & 151.42 & 5.0 & 5.0 & $50.83 \mathrm{~b}$ & $\mathrm{~S}$ & 170.42 & 5.0 & 5.0 & $59.24 \mathrm{a}$ & $\mathrm{S}$ \\
\hline ES N2010-12 & 105.67 & 5.0 & 5.0 & $38.71 \mathrm{~b}$ & $\mathrm{~S}$ & 83.83 & 5.0 & 5.0 & $22.67 \mathrm{a}$ & $\mathrm{S}$ \\
\hline ES N2010-13 & 105.4 & 4.83 & 4.67 & $17.38 \mathrm{c}$ & $\mathrm{S}$ & 105.42 & 4.83 & 4.83 & $4.84 \mathrm{c}$ & MR \\
\hline
\end{tabular}

$\mathrm{w} *$ indicates susceptible check.

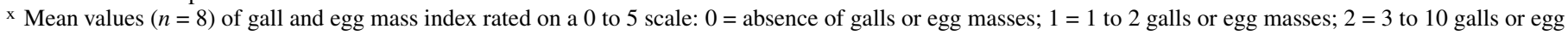
masses; $3=11$ to 30 galls or egg masses; $4=31$ to 100 galls or egg masses; and $5=$ over 100 galls or egg masses (54).

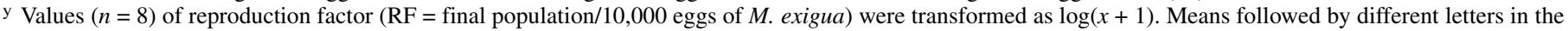
column are significantly different according to Scott-Knot's test $(P<0.05)$. Coefficients of variation $=33$ and $35 \%$.

${ }^{\mathrm{z}}$ Reaction of inoculated coffee genotypes: $\mathrm{S}=$ susceptible; $\mathrm{I}=$ immune; and $\mathrm{MR}=$ moderately resistant.

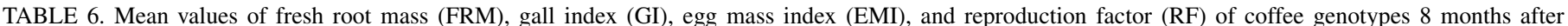
inoculation with virulent and avirulent Meloidogyne exigua under controlled conditions

\begin{tabular}{|c|c|c|c|c|c|c|c|c|c|c|}
\hline \multirow[b]{2}{*}{ Genotypes $^{\mathrm{w}}$} & \multicolumn{5}{|c|}{ Virulent $M$. exigua } & \multicolumn{5}{|c|}{ Avirulent $M$. exigua } \\
\hline & FRM (g) & $\mathrm{GI}^{\mathrm{x}}$ & $\mathrm{EMI}^{\mathrm{x}}$ & $\mathrm{RF}^{\mathrm{y}}$ & $\mathrm{R}^{\mathrm{z}}$ & FRM (g) & $\mathrm{GI}^{\mathrm{x}}$ & $\mathrm{EMI}^{\mathrm{x}}$ & $\mathrm{RF}^{\mathrm{y}}$ & $\mathrm{R}^{\mathrm{z}}$ \\
\hline Catuaí 'IAC 81 '* & 155.92 & 5.0 & 4.67 & $125.6 \mathrm{a}$ & $\mathrm{S}$ & 118.92 & 3.83 & 1.17 & $17.89 \mathrm{a}$ & S \\
\hline Clone 109A & 179.78 & 0.18 & 0.0 & $0.02 \mathrm{c}$ & HR & 211.17 & 0.0 & 0.0 & $0.01 \mathrm{~b}$ & HR \\
\hline Clone 120 & 106.83 & 0.0 & 0.0 & $0.04 \mathrm{c}$ & HR & 77.67 & 0.0 & 0.0 & $0.01 \mathrm{~b}$ & HR \\
\hline ES N2010-01 & 160.33 & 1.33 & 0.33 & $0.02 \mathrm{c}$ & HR & 147.25 & 0.17 & 0.0 & $0.0 \mathrm{~b}$ & I \\
\hline ES N2010-02 & 92.42 & 1.33 & 0.0 & $0.04 \mathrm{c}$ & HR & 114.25 & 0.0 & 0.0 & $0.01 \mathrm{~b}$ & HR \\
\hline ES N2010-03 & 108.5 & 0.0 & 0.0 & $0.02 \mathrm{c}$ & HR & 187.9 & 0.0 & 0.0 & $0.0 \mathrm{~b}$ & I \\
\hline ES N2010-04 & 125.6 & 0.2 & 0.0 & $0.02 \mathrm{c}$ & HR & 109.4 & 0.0 & 0.0 & $0.0 \mathrm{~b}$ & I \\
\hline ES N2010-05 & 88.9 & 0.2 & 0.0 & $0.27 \mathrm{c}$ & HR & 45.5 & 0.0 & 0.0 & $0.0 \mathrm{~b}$ & I \\
\hline ES N2010-06 & 254.08 & 0.0 & 0.0 & $0.0 \mathrm{c}$ & HR & 187.17 & 0.0 & 0.0 & $0.03 \mathrm{~b}$ & HR \\
\hline ES N2010-07 & 158.83 & 0.0 & 0.0 & $0.0 \mathrm{c}$ & HR & 117.42 & 0.0 & 0.0 & $0.01 \mathrm{~b}$ & HR \\
\hline ES N2010-08 & 183.08 & 2.33 & 1.83 & $0.08 \mathrm{c}$ & HR & 272.42 & 0.0 & 0.0 & $0.03 \mathrm{~b}$ & HR \\
\hline ES N2010-09 & 200.92 & 4.17 & 3.0 & $5.13 \mathrm{~b}$ & MR & 194.8 & 4.33 & 3.83 & $23.73 \mathrm{a}$ & $\mathrm{S}$ \\
\hline ES N2010-10 & 130.5 & 1.33 & 0.66 & $0.26 \mathrm{c}$ & HR & 223.5 & 0.0 & 0.0 & $0.11 \mathrm{~b}$ & HR \\
\hline ES N2010-11 & 86.67 & 0.67 & 0.33 & $0.01 \mathrm{c}$ & HR & 125.67 & 0.0 & 0.0 & $0.03 \mathrm{~b}$ & HR \\
\hline ES N2010-12 & 63.42 & 1.0 & 0.5 & $0.15 \mathrm{c}$ & HR & 66.5 & 0.0 & 0.0 & $0.01 \mathrm{~b}$ & HR \\
\hline ES N2010-13 & 119.5 & 0.33 & 0.17 & $0.0 \mathrm{c}$ & HR & 151.0 & 0.0 & 0.0 & $0.0 \mathrm{~b}$ & HR \\
\hline
\end{tabular}

$\mathrm{w} *$ indicates susceptible check.

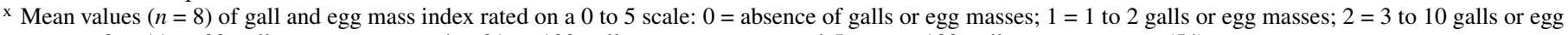
masses; $3=11$ to 30 galls or egg masses; $4=31$ to 100 galls or egg masses; and $5=$ over 100 galls or egg masses (54).

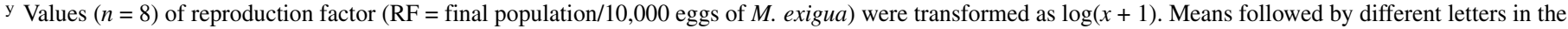
column are significantly different according to Scott-Knot's test $(P<0.05)$. Coefficients of variation $=27$ and $28 \%$.

${ }^{\mathrm{z}}$ Reaction of inoculated coffee genotypes: $\mathrm{S}=$ susceptible; $\mathrm{I}=$ immune; $\mathrm{HR}=$ highly resistant; and $\mathrm{MR}=$ moderately resistant.

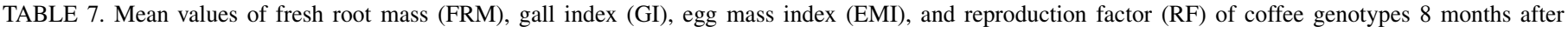
inoculation with Meloidogyne spp. under controlled conditions

\begin{tabular}{|c|c|c|c|c|c|c|c|c|c|c|}
\hline \multirow[b]{2}{*}{ Genotypes $^{w}$} & \multicolumn{5}{|c|}{ M. incognita race 3} & \multicolumn{5}{|c|}{ M. paranaensis } \\
\hline & FRM $(g)$ & $\mathrm{GI}^{\mathrm{x}}$ & $\mathrm{EMI}^{\mathrm{x}}$ & $\mathrm{RF}^{\mathrm{y}}$ & $\mathrm{R}^{\mathrm{z}}$ & FRM $(g)$ & $\mathrm{GI}^{\mathrm{x}}$ & $\mathrm{EMI}^{\mathrm{x}}$ & $\mathrm{RF}^{\mathrm{y}}$ & $\mathrm{R}^{\mathrm{z}}$ \\
\hline Catuaí 'IAC $81^{\prime} *$ & 44.3 & 4.9 & 4.8 & $36.2 \mathrm{a}$ & S & 46.2 & 4.5 & 5.0 & 32.5 & S \\
\hline Clone 14 & 40.6 & 2.2 & 0.5 & $0.28 \mathrm{c}$ & $\mathrm{R}$ & 43.0 & 2.2 & 0.0 & 0.35 & $\mathrm{R}$ \\
\hline Clone 22 & 56.1 & 3.4 & 4.7 & $8.4 \mathrm{~b}$ & $\mathrm{~S}$ & 38.4 & 3.28 & 4.71 & 18.05 & S \\
\hline
\end{tabular}

$\mathrm{w} *$ indicates susceptible check.

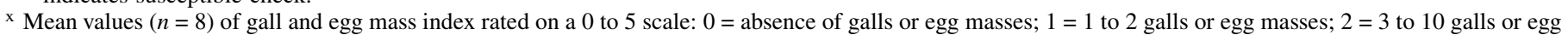
masses; $3=11$ to 30 galls or egg masses; $4=31$ to 100 galls or egg masses; and $5=$ over 100 galls or egg masses (54).

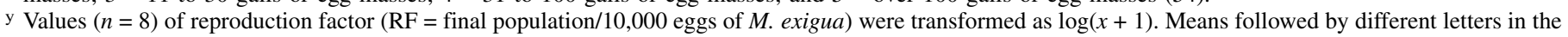
column are significantly different according to Scott-Knot's test $(P<0.05)$. Coefficients of variation $=21$ and $23 \%$.

${ }^{\mathrm{z}}$ Reaction of inoculated coffee genotypes: $\mathrm{S}=$ susceptible; and $\mathrm{R}=$ resistant. 
with nematodes and surrounding giant cells (Fig. 2E to $\mathrm{H}$ ). Although at 32 to 45 DAI young females with developed early stages of ovaries were observed; no egg masses were seen (Fig. $2 \mathrm{G}$ to $\mathrm{H})$.

External observations of roots at 45 to 50 DAI revealed large and well-developed swelling or small galls in susceptible roots, whereas in resistant roots nothing was observed. Acid fuchsin-stained roots at 45 to 50 DAI revealed that in susceptible clone 22, females had reached reproductive maturity and begun to lay eggs, whereas in resistant roots the underdeveloped females showed no signs of egg production. These results agree with those obtained from coffee genotype inoculations (Tables 1 to 7 ).

\section{DISCUSSION}

The identification and selection of $C$. canephora clones combining drought tolerance with other agronomic traits (e.g., efficient flowering, productivity, and vigor) and multiple-resistance to RKN is of particular interest in generating new varieties better adapted to climate changes and biotic stress (27,29,31). All 30 C. canephora genotypes screened in this work had never been tested against Meloidogyne spp. populations.
Plant genotypes can be evaluated for RKN resistance based on levels of galling, egg mass number, and total number of eggs collected from infected roots. However, for some crops root galling is not a completely satisfactory indicator of RKN resistance (suppressed reproduction) (41). The galling and egg mass indexes were not a reliable indicator of nematode multiplication rates because of damage symptoms caused by different Meloidogyne spp., on coffee were variable and difficult to quantify. Based on these findings, the most pertinent parameter for assessing Meloidogyne spp. reproduction on coffee germplasms and the resistance status of these coffee genotypes to several Meloidogyne spp. populations are the number of eggs per gram of roots or the nematode reproduction factor. Our findings agree with results reported by Muniz et al. (45) for $C$. arabica and disagree with those reported by Hernandez et al. (38), who considered galling index as a relatively good indicator of Meloidogyne multiplication rate on coffee. Considering these contradictory results, these indexes are also included in this work. Hussey and Boerma (40) recommended a preliminary test to determine whether there is a strong correlation among galling, egg masses, and nematode reproduction rate.

Our results demonstrate that only clone 14 showed high multiple resistance to $M$. exigua, $M$. incognita races 1 and 3 , and
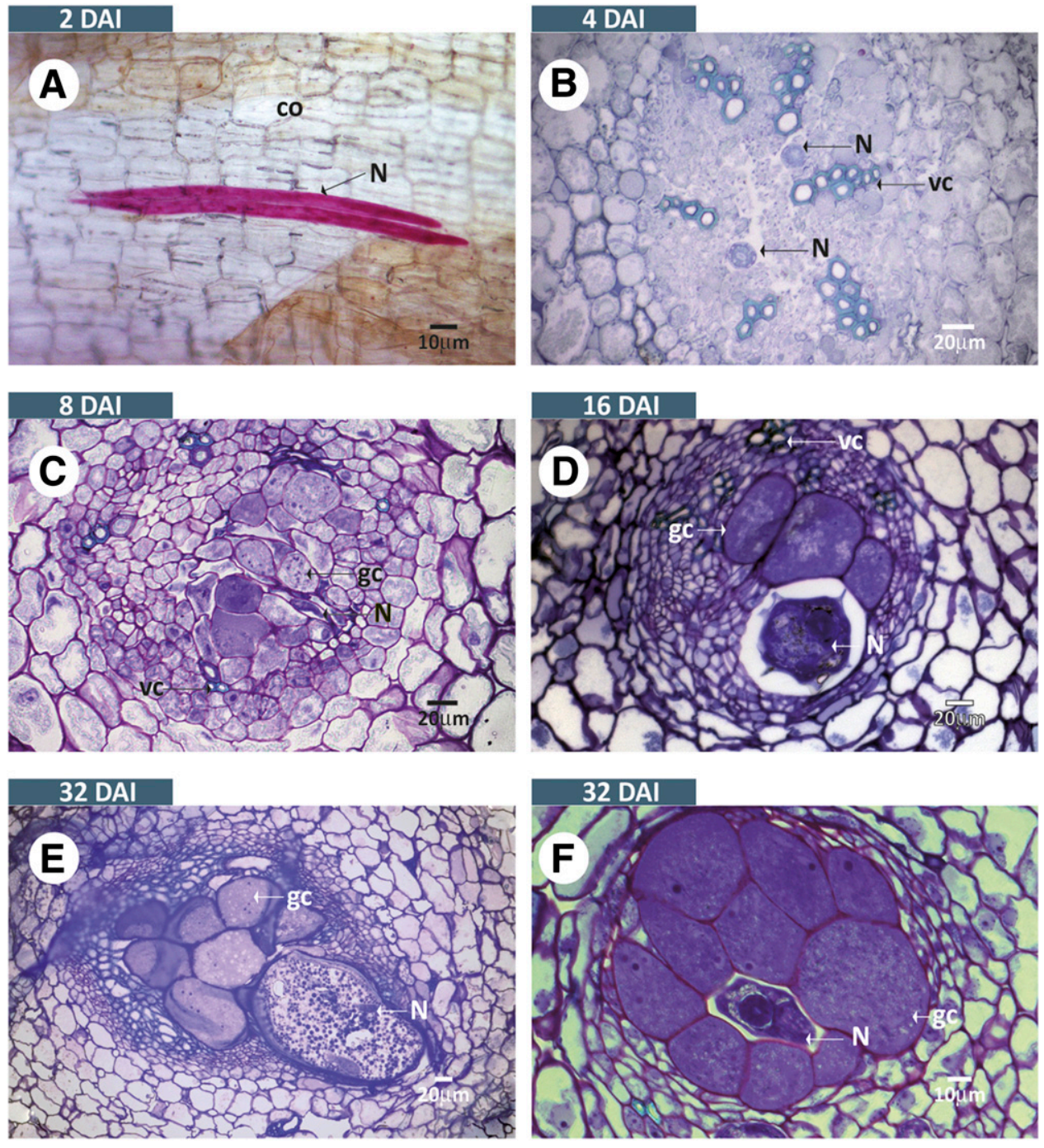

Fig. 1. Root sections of Coffea canephora clonal variety clone 22 (susceptible control) infested with Meloidogyne paranaensis. A, Fuchsine acid staining: secondstage juvenile (J2) nematodes located in the root cortex 2 days after inoculation (DAI). B to F, Toluidine blue staining; B, intercellular localization of a J2 nematode in the central cylinder; $\mathbf{C}, \mathrm{J} 2 / \mathrm{J} 3$ nematodes close to initial giant cells inside the central cylinder; $\mathbf{D}, \mathbf{E}$, and $\mathbf{F}$, J4 or female nematodes close to giant cells that display dense cytoplasm, vacuoles, and thickened blue-stained cell walls. $\mathrm{N}=$ nematode, $\mathrm{gc}=$ giant cells, $\mathrm{co}=\mathrm{cortex}, \mathrm{vc}=\mathrm{vascular}$ cylinder. Sections visualized after staining with acid fuchsin (A) and toluidine-blue (B to F). 
M. paranaensis, with HR-like lesions as suggested by histological observations. In contrast, clone 22 was susceptible to these RKN species. Specific resistance to either $M$. exigua, M. incognita, M. paranaensis or Meloidogyne spp. was also found in coffee germplasm lines $(11,17)$, however, multiple resistance was usually not found -i.e., it was restricted to one or two Meloidogyne species. This was the case in our study in which some genotypes were resistant or moderately resistant to one or two Meloidogyne spp., except for clone 14, which showed high levels of resistance to five RKN populations. Similarly, cultivar IAPAR 59 harboring the Mex-1 gene is only resistant to M. exigua (11).

The widespread distribution of Meloidogyne spp. in Brazil and Central America, along with its high aggressiveness led nematologists to look for alternatives to chemical control $(28,55,57)$. For example, an accession of $C$. canephora '2258' from Catie's germplasm collection in Costa Rica showed high resistance to
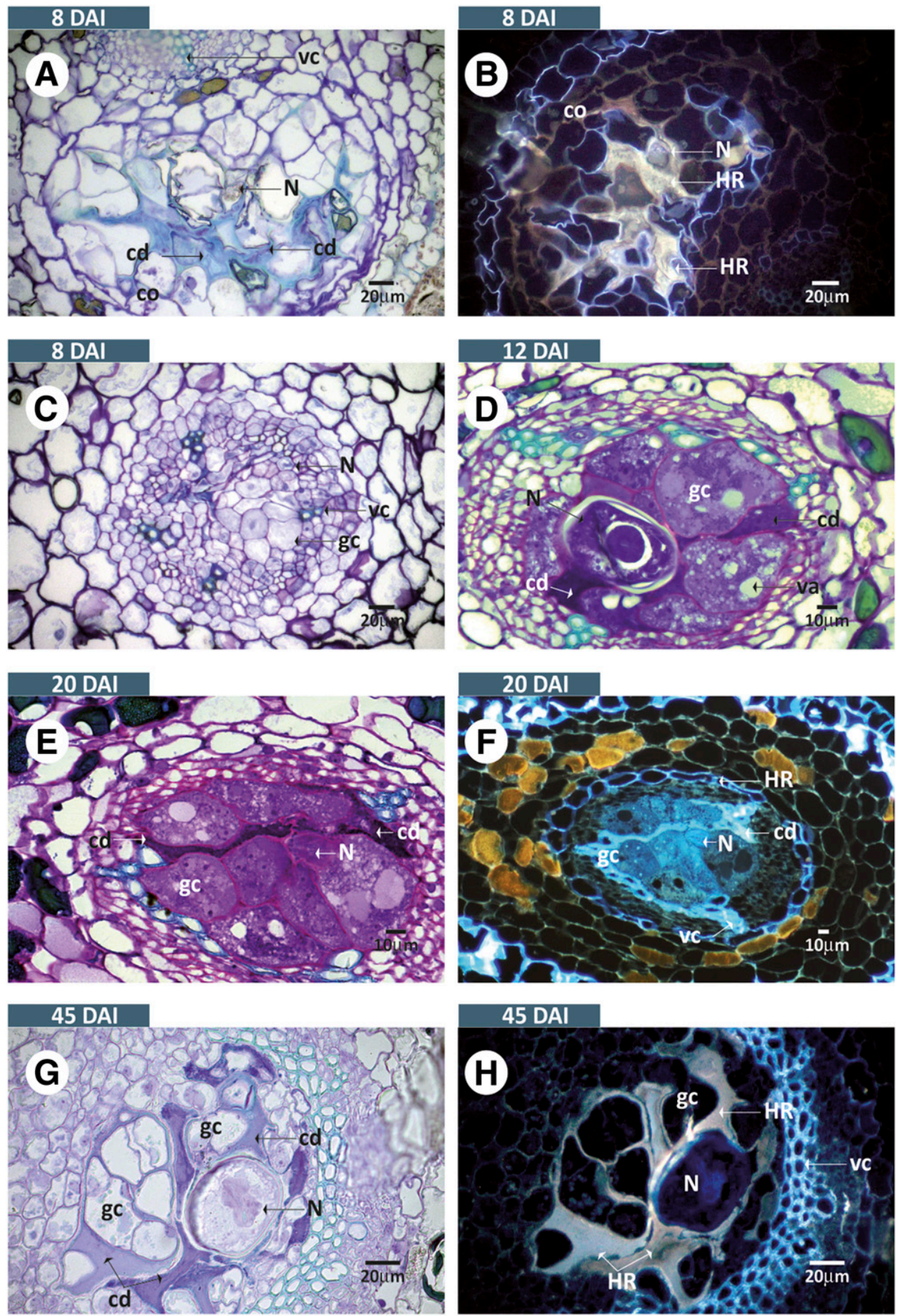

Fig. 2. Root sections of Coffea canephora clonal variety clone 14 (resistant) infested with Meloidogyne paranaensis. A, C, D, E, and G, Toluidine blue staining; B, F, and H, UV fluorescence observation. A and B, Second-stage juvenile (J2) nematode located in the root cortex and surrounded by blue-stained degraded cells (A) which display a yellow fluorescence under UV illumination (B); C, D, E, F, G, and H, nematodes present in the vascular cylinder. Giant cells can be observed 8 days after inoculation associated with the presence of nematodes (C). A blue-gray fluorescence is seen in cells near the nematode and in walls of vessels ( $F$ and H); D, E, and G, parenchyma cells close to J2s exhibiting a dark-stained material, suggesting severe alteration of the cytoplasm; $\mathbf{E}$ and $\mathbf{G}$, giant cells showing retracted cytoplasm containing numerous vacuoles. $\mathrm{N}=$ nematode, $\mathrm{HR}=$ hypersensitive reaction indicating cell death $(\mathrm{cd}), \mathrm{co}=\mathrm{cortex}, \mathrm{gc}=\mathrm{giant}$ cells, $\mathrm{vc}=$ vascular cylinder, va = vacuole. Sections visualized under UV light $(\mathrm{B}, \mathrm{F}$, and $\mathrm{H})$ and after staining with toluidine blue $(\mathrm{A}, \mathrm{C}, \mathrm{D}, \mathrm{E}$, and $\mathrm{G})$. 
M. exigua and resistance and/or tolerance to $M$. incognita populations (24). The same accession was later reported as resistant to $M$. incognita races 1,2 , and $3(32,35)$ and to $M$. paranaensis $(26)$. Initially, the '2258' accession had a resistance level around 70\%; however, this level has been raised considerably by subsequent selection in fields infested by $M$. incognita. This improved line was later released as 'Apoatã', a rootstock resistant to Meloidogyne spp. (26). 'Nemaya', another multi-resistant rootstock (cross between the $C$. canephora clones 'T3561' and 'T3751'), was developed to overcome major problems associated with RKNs in Central America $(7,14)$ and can be reproduced through seeds. Somatic embryogenesis had to be used to speed up propagation of mother plants (15). Unfortunately, in Central America and Brazil C. canephora rootstocks 'Nemaya' and 'Apoatã' encountered serious reduction in growth and yield related to sensitivity to low temperatures and drought, respectively (12; W. Gonçalves, IAC, São Paulo, Brazil, personal communication). As a consequence of global warming, extended periods of drought and an increase in nematode populations are now key factors affecting coffee plant development and production (21). The identification of RKN multiresistant coffee rootstock with drought tolerance, like Conilon clone 14 , has now turned into one of the priorities for many coffee research institutes.

In the present study, resistance of $C$. canephora clone 14 to Meloidogyne spp. was confirmed and characterized at the histological level. Defense mechanisms associated with resistance to $M$. incognita race 3 and $M$. paranaensis resulted in (i) reduced penetration of roots by few $\mathrm{J} 2$, (ii) early appearance of HR-like symptoms during invasion of cortex cells by the nematodes, and (iii) altered feeding sites localized next to strong HR-like areas.

The failure of $\mathrm{J} 2$ to penetrate the roots of clone 14 indicates the occurrence of physical and/or chemical barriers. Such barriers were suggested previously for resistant grape rootstock $(4,30)$, cotton (5), soybean 256 (23), pepper (47), coffee IAPAR 59 (3), and peanut (49). Besides these barriers, at least two additional mechanisms could be involved in the expression of resistance. One occurs around 8 DAI, which blocks development of $\mathrm{J} 2$ that have penetrated the roots, as observed for other $\mathrm{RKN}-C$. arabica interactions $(1,3)$. Microscopic investigation showed that degradation of plant cells in contact with penetrating or migrating J2s at 6 to $8 \mathrm{DAI}$ is closely concomitant to the arrest of nematode development. This observation is in accordance with previous reports on HR-like response involved in resistance against nematodes in other plant species, including cotton (44), peanut (49), and pepper (47). These HR-like areas in infected cortical cells displayed a gray-blue autofluorescence under UV light, indicating a possible presence of phenols that could play a role in coffee defense strategy $(1,3)$. Other research (47) has identified chlorogenic acid as a major phenolic compound present in root extract of inoculated RKN-resistant pepper. Likewise, (3) demonstrated that resistance conferred by the Mex-1 gene introgressed from C. canephora into the coffee Iapar 59 genome is strongly associated with a HR phenotype. Correlatively, differential staining with toluidine-blue also revealed the same early HR staining observed in clone 14 . This interesting feature was also seen lately in infected resistant roots, with the occurrence of feeding sites and nematodes close to dead cells or HR-like areas. Until 20 DAI, giant cells in this cultivar were easily recognized by their increased size, presence of some small nuclei and vacuole-like structure and small cell death. After this time, 32 to 45 DAI, the cytoplasm degradation of giant cells, the dark blue (cell death) and blue-green coloration (HR) next to nematodes and feeding sites were strongly visible, suggesting accumulation of phenolic compounds. These degraded giant cells were frequently associated with collapsed young females. These results suggest that the defense response of $C$. canephora roots was activated later and are related to inhibition and degradation of nematodes feeding sites, rather than obstruction of nematode infection and migration through the roots. This late mechanism seems to be the most important in the Conilon clone 14 pathosystem.

In coffee, the HR in root cells of clone 14 triggered by $M$. paranaensis and $M$. incognita infection may be indicative of a specific gene-for-gene interaction. This would suggest that resistance to Meloidogyne spp. in this clone is probably controlled by more than one resistance gene, which could be used to produce new coffee varieties resistant to RKNs. Currently, a segregating population has been built up for mapping and further investigation of the resistance gene(s) that could control clone 14-RKN interactions. Improvement of coffee plants to achieve RKN resistance is crucial for most coffeeproducing countries and could be even more urgent in the near future, given the negative impact that climate change will have on coffee crops (32).

Traditional breeding programs usually rely on related diploid species $C$. canephora or $C$. racemosa as sources of resistance to RKN (43). However, the crossing limitations of this strategy incur high costs and long-term investments to develop new coffee cultivars that combine good cup quality and resistance to parasites. Another strategy consists in using selected resistant $C$. canephora as rootstocks. In Costa Rica, Guatemala, and Brazil, grafting onto robusta rootstocks is effective in the field, with productivity of the grafted plants being four times higher than ungrafted plants (56). The use of resistant rootstocks constitutes an inexpensive, nonpolluting, and efficient control method. Compared with viruses, bacteria, or fungi, RKNs are characterized by low natural dispersal, gene flow, and genetic diversity between populations (51). This leads to a durable resistance in clone 14 that combines multiple resistance to RKN and drought tolerance in a unique clonal variety. These results provide rational bases for future studies involving gene expression analysis, which will reveal the resistance of clone 14 to RKNs at a molecular level.

\section{ACKNOWLEDGMENTS}

This work was supported by Embrapa Café, Embrapa Recursos Genéticos e Biotecnologia and Conselho Nacional de Desenvolvimento Científico e Tecnológico (CNPq). E. A. Lima thanks CAPES for her scholarship.

\section{LITERATURE CITED}

1. Albuquerque, E. V. S., Carneiro, R. M. D. G., Costa, P. M., Gomes, A. C. M. M., Santos, M., Pereira, A. V., Nicole, M., Fernandez, D., and Grossi-De-Sá, M. F. 2010. Resistance to Meloidogyne incognita expresses a hypersensitive-like response in Coffea arabica. Eur. J. Plant Pathol. 127: 365-373.

2. Anthony, F., Topart, P., and Anzueto, F. 2003. La resistencia genética de Coffea spp. a Meloidogyne paranaensis: identificación y utilización para la cafeicultura latinoamericana. Manejo Integrado Pragas Agroecol. 67: 4-11.

3. Anthony, F., Topart, P., Martinez, A., Silva, M., and Nicole, M. 2005. Hypersensitive-like reaction conferred by the Mex-1 resistance gene against Meloidogyne exigua in coffee. Plant Pathol. 54:476-482.

4. Anwar, S. A., and McKenry, M. V. 2000. Penetration, development and reproduction of Meloidogyne arenaria on two new resistant Vitis spp. Nematropica 3:9-17.

5. Anwar, S. A., Trudgill, D. L., and Philipps, M. S. 1994. The contribution of variation in invasion and development rates of Meloidogyne incognita to host status differences. Nematologica 40:579-586.

6. Anzueto, F., Bertrand, B., Pena, M., Marban-Mendonza, N., Villain, L., and Ibarra, E. L. 1996. Desarrollo de una variedad porta-injerto resistente a los principales nematodos de América Central. XVII Simp. Caficultura Latinoam. Mem. 1:1-6.

7. Anzueto, F., Bertrand, B., Sarah, J. L., Eskes, A. B., and Decazy, B. 2001. Resistance to Meloidogyne incognita in Ethiopian Coffea arabica accessions. Euphytica 118:1-8.

8. Anzueto, F., Eskes, A. B., and Sarah, J. L. 1991. Pages 534-543 in: Recherche de la resistance à Meloidogyne sp. dans une collection de Coffea arabica. XIV Intern. Sci. Colloq. Coffee Proc, San Francisco, CA. 
9. Arango, L. G., Baeza, C. A., and Leguizamon, J. E. 1982. Pages 563-568 in: Pruebas de resistencia a espécies de Meloidogyne en plántulas de Coffea spp. X Intern. Sci. Colloq. Coffee Proc, Salvador, Brazil.

10. Bertrand, B., Aguilar, G., and Bompard, E. 1997. Comportement agronomique et résistance aux principaux déprédateurs des lignées de Sarchimor et Catimor au Costa Rica. Plant. Rech. Dev. 4:312-321.

11. Bertrand, B., and Anthony, F. 2008. Genetics of resistance to root-knot nematodes (Meloidogyne spp.) and breeding. Pages 165-190 in: PlantParasitic Nematodes of Coffee. R. M. Souza, ed. Springer, Berlin, Germany.

12. Bertrand, B., Anthony, F., and Lashermes, P. 2001. Breeding for resistance to Meloidogyne exigua in Coffea arabica by introgression of resistance genes of Coffea canephora. Plant Pathol. 50:637-643.

13. Bertrand, B., Anzueto, F., and Peña, M. X. 1995. Pages 630-636 in: Genetic improvement of coffee for resistance to root-knot nematodes (Meloidogyne spp.) in Central America. X Intern. Sci. Colloq. Coffee Proc., Salvador, Brazil.

14. Bertrand, B., Peña-Durán, M. X., Anzueto, F., Cilas, C., Etiene, H., Anthony, F., and Eskes, A. B. 2000. Genetic study of Coffea canephora coffee tree resistance to Meloidogyne incognita nematodes in Guatemala and Meloidogyne sp. nematodes in El Salvador for selection of rootstock varieties in Central America. Euphytica 113:79-86.

15. Bertrand, B., Ramirez, G., Topart, P., and Anthony, F. 2002. Resistance of cultivated coffee (Coffea arabica and C. canephora) trees to corky-root caused by Meloidogyne arabicida and Fusarium oxysporum, under controlled and field conditions. Crop Prot. 21:713-719.

16. Boisseau, M., Aribi, J., De-Sousa, F. R., Carneiro, R. M. D. G., and Anthony, F. 2009. Resistance to Meloidogyne paranaensis in wild Coffea arabica. Trop. Plant Pathol. 34:38-41.

17. Campos, V. P., and Villain, L. 2005. Nematode parasites of coffee and cocoa. Pages 529-579 in: Plant-Parasitic Nematodes in Subtropical and Tropical Agriculture. M. Luc, R. A. Sikora, and J. Bridge, eds. CAB International, Wallingford, UK.

18. Carneiro, R. M. D. G., and Almeida, M. R. A. 2001. Técnica de eletroforese usada no estudo de enzimas dos nematoides de galhas para identificação de espécies. Nematol. Bras. 25:35-44.

19. Carneiro, R. M. D. G., and Cofcewicz, E. T. 2008. Taxonomy of coffeeparasitic root-knot nematodes, Meloidogyne spp. Pages 87-122 in: PlantParasitic Nematodes of Coffee. R. M. Souza, ed. Springer, Berlin, Germany.

20. Curi, S. M., Carvalho, A., Moraes, F. P., Mônaco, L. C., and De-Arruda, H. V. 1970. Novas fontes de resistência genética de Coffea no controle do nematóide do cafeeiro, Meloidogyne exigua. O Biológico 35:41-44.

21. Da Matta, F. M., and Ramalho, J. C. 2006. Impacts of drought and temperature stress on coffee physiology and production: A review. Braz. J. Plant Physiol. 18:55-81.

22. Da Matta, F. M., Silveira, J. S. M., Ducatti, C., and Loureiro, M. E. 2010. Eficiência do uso da água e tolerância à seca em Coffea canephora. Pages 907-910 in: I Simpósio de Pesquisa dos Cafés do Brasil, Vol. 2. EMBRAPA, Brasília.

23. Dropkin, V. H., and Nelson, P. E. 1960. The histopathology of root-knot nematode infections in soybeans. Phytopathology 50:442-447.

24. Fazuoli, L. C. 1986. Genética e melhoramento do cafeeiro. Pages 87-113 in: Cultura do Cafeeiro: Fatores que Afetam a Produtividade. A. B. Rena, E. Malavolta, M. Rocha, and T. Yamada, eds. POTAFOS, Piracicaba, Brazil.

25. Fazuoli, L. C., and Lordello, R. A. 1978. Resistência de cafeeiros Híbrido do Timor a Meloidogyne exigua. Cienc. Cult. 30:3.

26. Fazuoli, L. C., Medina-Filho, H. P., Gonçalves, W., Guerreiro-Filho, O., and Silvarolla, M. B. 2002. Melhoramento do cafeeiro: Variedades tipo arábica obtidas no Instituto Agronômico de Campinas. Pages 162-215 in: O Estado da Arte de Tecnologia de Produção De Café. L. Zambolin, ed. Editora UFV, Viçosa, Brazil.

27. Ferrão, M. A. G., Ferrão, R. G., Fonseca, A. F. A., Verdin-Filho, A. C., and Volpi, P. S. 2010. Origem, dispersão geográfica, taxonomia e diversidade genética de Coffea canephora. Pages 67-91 in: Café Conilon. R. G. Ferrão, A. F. A. Fonseca, S. M. Bragança, M. A. G. Ferrão, and L. H. De-Muner. DCM Incaper, Vitória, Brazil.

28. Ferrão, R. G., Fonseca, A. F. A., Ferrão, M. A. G., and Santos, L. P. 2000. Avaliação de clones elites de café conilon em condições de estresse hídrico no estado do Espírito Santo. Pages 402-404 in: I Simpósio de Pesquisa dos Cafés do Brasil, Vol. I. EMBRAPA, Brasília.

29. Ferraz, L. C. C. B. 2008. Plant parasitic nematodes of coffee in Brazil. Pages 225-248 in: Plant-Parasitic Nematodes of Coffee. R. M. Souza, ed. Springer, Berlin, Germany.

30. Ferris, H., Schneider, S. M., and Stuth, M. C. 1982. Probability of penetration and infection by root-knot nematode, Meloidogyne arenaria, in grape cultivars. Am. J. Enol. Vitic. 33:31-35.

31. Fonseca, A. F. A., Ferrão, M. A. G., Ferrão, R. G., Verdin-Filho, A. C., Volpi, P. S., and Zucateli, F. 2004. Conilon Vitória 'Incaper 8142': Variedade clonal de café conilon. Incaper Doc. 127:1-24.
32. Ghini, R., Hamada, E., Pedro-Júnior, M. J., Marengo, J. A., and Gonçalves, R. R. V. 2008. Risk analysis of climate change on coffee nematodes and leaf miner in Brazil. Pesquisa Agropecu. Bras. 43:187-193.

33. Gonçalves, W., and Ferraz, L. C. C. B. 1987. Resistência do cafeeiro a nematóides. II. Testes de progênies e híbridos para Meloidogyne incognita raça 3. Nematol. Bras. 11:125-142.

34. Gonçalves, W., Ferraz, L. C. C. B., De-Lima, M. M. A., and Silvarolla, M. B. 1996. Patogenicidade de Meloidogyne exigua e M. incognita raça 1 a mudas de cafeeiros. Bragantia 55:89-93.

35. Gonçalves, W., Ferraz, L. C. C. B., De-Lima, M. M. A., and Silvarolla, M. B. 1996. Reações de cafeeiros às raças 1, 2 e 3 de Meloidogyne incognita. Summa Phytopathol. 22:172-177.

36. Gonçalves, W., and Pereira, A. A. 1998. Resistência do cafeeiro a nematóides IV-Reação de cafeeiros derivados do Híbrido de Timor a Meloidogyne exigua. Nematol. Bras. 22:39-50.

37. Hartman, K. M., and Sasser, J. N. 1985. Identification of Meloidogyne species on the basis of differential host test and perineal pattern morphology. Pages 69-77 in: An Advanced Treatise on Meloidogyne, Volume II: Methodology. K. R. Barker, C. C. Carter, and J. N. Sasser, eds. North Carolina State University Graphics, Raleigh.

38. Hernandez, A., Fargette, M., and Sarah, J. L. 2004. Pathogenicity of Meloidogyne spp. (Tylenchida: Meloidogynidae) isolates from Central America and Brazil on four genotypes of Coffea arabica. Nematology 6: 205-213

39. Hussey, R. S., and Barker, K. R. 1973. A comparison of methods of collecting inocula for Meloidogyne spp., including a new technique. Plant Dis. Rep. 57:1025-1028.

40. Hussey, R. S., and Boerma, H. R. 1981. A greenhouse screening procedures for root knot nematode resistance in soybean. Crop Sci. 21:794-796.

41. Hussey, R. S., and Janssen, G. J. W. 2002. Root-knot nematodes: Meloidogyne species. Pages 43-70 in: Plant Resistance to Parasitic Nematodes. J. L. Starr, R. Cook, and J. Bridge, eds. CAB International, Wallingford, UK.

42. López-Chaves, R., and Salazar-Figueroa, L. 1989. Meloidogyne arabicida sp.n. (Nemata: Heteroderidae) nativo de Costa Rica: Un nuevo y severo patógeno del cafeto. Turrialba 39:313-323.

43. Maluf, M. P. 2008. Genomic tools for the development of engineered Meloidogyne-resistant coffee cultivars. Pages 191-205 in: Plant-Parasitic Nematodes of Coffee. R. M. Souza, ed. Springer, Berlin, Germany.

44. Mota, F. C., Alves, G. C. S., Giband, M., Gomes, A. C. M. M., Sousa, F. R., Mattos, V. S., Barbosa, V. H. S., Barroso, P. A. V., Nicole, M., Peixoto, J. R., Rocha, M. R., and Carneiro, R. M. D. G. 2013. New sources of resistance to Meloidogyne incognita race 3 in wild cotton accessions and histological characterization of the defence mechanisms. Plant Pathol. 62:1173-1183.

45. Muniz, M. F. S., Campos, V. P., Moita, A. W., Gonçalves, W., Almeida, M. R. A., Sousa, F. R., and Carneiro, R. M. D. G. 2009. · Reaction of coffee genotypes to different populations of Meloidogyne spp.: Detection of a naturally virulent $M$. exigua population. Trop. Plant Pathol. 34:370-378.

46. Noir, S., Anthony, F., Bertrand, B., Combes, M. C., and Lashermes, P. 2003. Identification of a major gene (Mex-1) from Coffea canephora conferring resistance to Meloidogyne exigua in Coffea arabica. Plant Pathol. 52:97-103.

47. Pegard, A., Brizzard, G., Fazari, A., Soucaze, O., Abad, P., and Caparalino, C. D. 2005. Histological characterization of resistance to different root-knot nematode species related to phenolics accumulation in Capsicum annuum. Phytopathology 95:158-165.

48. Pinheiro, H. A., Da Mata, F. M., Chaves, A. R. M., Loureiro, M. E., and Ducatti, C. 2005. Drought tolerance is associated with rooting depth and stomatal control of water use in clones of Coffea canephora. Ann. Bot. (Lond.) 96:101-108

49. Proite, K., Carneiro, R., Falcão, R., Gomes, A., Leal-Bertioli, S., Guimarães, P., and Bertioli, D. 2008. Post-infection development and histopathology of Meloidogyne arenaria race 1 on Arachis spp. Plant Pathol. 57:974-980.

50. Randig, O., Bongiovanni, M., Carneiro, R. M. D. G., and Castagnone-Sereno, P. 2002. Genetic diversity of root-knot nematodes from Brazil and development of SCAR markers specific for the coffeedamaging species. Genome 45:862-870.

51. Santos, M. F. A., Furlanetto, C., Almeida, M. R. A., Carneiro, M. D. G., Mota, F. C., Mendes, A. C. M., Silveira, N. O. R., Silva, J. G. P., Tigano, M. S., and Carneiro, R. M. D. G. 2012. Biometrical, biological, biochemical and molecular characteristics of Meloidogyne incognita isolates and related species. Eur. J. Plant Pathol. 134:671-684.

52. Sasser, J. N., Carter, C. C., and Hartman, R. M. 1984. Standardization of host suitability studies and reporting of resistance to root-knot nematodes. North Carolina State University Graphics, Raleigh, NC.

53. Silvarolla, M. B., Gonçalves, W., and Marinez, M. A. L. 1998. Resistência do cafeeiro a nematóides V-Reprodução de Meloidogyne exigua em 
cafeeiros derivados da hibridação de Coffea arabica com C. canephora. Nematol. Bras. 22:51-59.

54. Taylor, A. L., and Sasser, J. N. 1978. Biology, identification and control of root-knot nematodes (Meloidogyne species). North Carolina State University Graphics, Raleigh, NC.

55. Villain, L., Hernández, A., and Anzueto, F. 2008. Central América. Pages 261-275 in: Plant-Parasitic Nematodes of Coffee. R. M. Souza, ed. Springer, Berlin, Germany.
56. Villain, L., Molina, A., and Sierra, S. 2000. Effect of grafting and nematicides treatment on damage by root-lesion nematodes (Pratylenchus spp.) to Coffea arabica L. in Guatemala. Nematropica 30: 87-100.

57. Villain, L., Sarah, J. L., Hernández, A., Bertrand, B., Anthony, F., Lashermes, P., Charmetant, P., Anzueto, F., Figueroa, P., and Carneiro, R. M. D. G. 2013. Diversity of root-knot nematodes associated with coffee orchards in Central America. Nematropica 43:194-206. 